\title{
Evaluasi Potensi Lahan Pengembangan Komoditas Strategis Perkebunan Kabupaten Sumba Tengah, Provinsi Nusa Tenggara Timur
}

\section{Evaluation Land Potential in The Development Of Commodities Strategic Plantations in Central Sumba Regency, East Nusa Tenggara Province}

\author{
Uska Peku Jawang $^{1 *}$, Bistok Hasiholan Simanjuntak ${ }^{1}$, Tinjung Mary Prihtanti ${ }^{1}$ \\ ${ }^{1 *}$ Magister Ilmu Pertanian, Fakultas Pertanian dan Bisnis, Universitas Kristen Satya Wacana Salatiga, Jawa Tengah \\ *Email: 532015002@student.uksw.edu \\ Diterima / Disetujui
}

\begin{abstract}
There are four strategic commodity plantations developed in the region of Central Sumba Regency coffee, cocoa, cashew and candlenut. Imformation. land development potential of strategic commodities is still limited. Research purposes: 1) determines the superiority of the selected commodity, 2) land suitability, and 3) Landing area development. Research method: the study of literature, superiority of the selected commodity the method of LQ, land sustability classes in particular with matching methods of land characteristics and plant growt requirement, and selected areas of commodity base, Cocoa in district: Katiku Tana, South Katiku Tana, and Mamboro. Coffee in district: Katiku Tana and South Katiku Tana.Cashew in district Mamboro and Umbu Ratu Nggay. Candlenut in district: Mamboro and West Umbu Ratu Nggay. The area class land suitability of commodities. Cocoa with class S1: S2:103,327.5 ha, 83,365.4 ha and N: 225 ha. Coffee with class S1, S2:123,664 ha 63,027.7 ha and N: 226. Cashew with class S1: S2:5,716 ha, 126,661.3 ha, 54,313.1 ha: S3 and N: 228 ha. Candlenut with class S1: S2:165,567 ha, 21,128.3 ha and N: $223 \mathrm{ha}$. The direction of commodities development area based on the potential of the land. Cocoa in district Katiku Tana, South Katiku Tana and Mamboro. Coffee in district Katiku Tana and South Katiku Tana. Cashew enough potential development area in district Mamboro, Umbu Umbu Ratu Nggay and West Umbu Ratu Nggay. The regions development candlenut in district South Katiku Tana, Mamboro, and West Umbu Ratu Nggay.
\end{abstract}

Keywords: evaluation of the potential of the land, land suitability class, the direction of development of the region, the leading commodity plantations,

\section{ABSTRAK}

Terdapat empat komoditi strategis perkebunan yang dikembangkan di wilayah Kabupaten Sumba Tengah yaitu kopi, kakao, jambu mete dan kemiri. Informasi potensi lahan pengembangan komoditi strategis masih terbatas. Tujuan penelitian: 1) Menentukan keunggulan komoditi terpilih, 2) Kesesuaian lahan, dan 3) Arahan wilayah pengembangan. Metode penelitian: Studi literature, Komoditas unggulan dengan metode LQ, Kelas kesesuaian lahan secara spasial dengan metode matching krakteristik lahan dan persyaratan tumbuh tanaman, dan arahan wilayah potensi pengembangan. Komoditas terpilih dengan wilayah basis. Kakao di Kecamatan: Katiku Tana, Katiku Tana Selatan, dan Mamboro. Kopi di Kecamatan: Katiku Tana dan Katiku Tana Selatan. Jambu Mete di Kecamatan Mamboro dan Umbu Ratu Nggay. Kemiri di Kecamatan : Mamboro dan Umbu Ratu Nggay Barat. Tingkat luas wilayah kelas kesesuaian lahan komoditas, Kakao dengan luas kelas S1: 103.327,5 ha, S2: 83.365,4 ha dan N: 225 ha. Kopi dengan luas kelas S1 123.664 ha, S2: 63.027,7 ha dan N: 226. Jambu mete dengan luas kelas S1: 5.716 ha, S2: 126.661,3 ha, S3: 54.313,1 ha dan N: 228 ha. Kemiri dengan luas kesesuian kelas S1: 165.567 ha, S2: 21.128,3 ha dan N: 223 ha. Arah wilayah pengembangan komoditas berdasarkan potensi lahan. Kakao di Kecamatan Katiku Tana, Katiku Tana Selatan dan Mamboro. Kopi di kecamatan Katiku Tana dan Katiku Tana Selatan. Jambu Mete wilayah pengembangan cukup potensi di kecamatan Mamboro, Umbu Ratu Nggay dan Umbu Ratu Nggay Barat. Kemiri wilayah pengembangan di kecamatan Katiku Tana Selatan, Mamboro dan Umbu Ratu Nggay Barat.

Kata kunci: evaluasi potensi lahan, komoditas unggulan perkebunan, kelas kesesuaian, arahan pengembangan wilayah.

\section{PENDAHALUAN}

Setiap wilayah berupaya untuk membangun wilayahnya demi memenuhi kebutuhan wilayah, sehingga wilayah memiliki rencana dalam membangun daerahnya demi meningkatkan ekonomi wilayah dan kesejahteraan masyarakat. Upaya yang perlu dilakukan adalah mengetahui kekuatan, kelemahan, peluang dan ancaman yang terdapat diwilayah, karena setiap wilayah memiliki karakternya masing-masing atau persoalan yang adapun dapat berbeda.

Uska Peku Jawang , Bistok Hasiholan Simanjuntak, Tinjung Mary Prihtanti... 
Dalam perencaan pembangunaan wilayah maka perlu diperhatikan adalah sektor yang menjadi unggulan wilayah, seperti daya dukung sumber daya alam, sumber daya manusia maupun sumberdaya lainnya. Menurut (Mawardi, 2007) menjelaskan bahwa setiap daerah perlu adanya prioritas pembangunan dengan memperhatikan keterbatasan wilayah yang ada dengan memaksimalkan keunggulan wilayah yang mendukung pembangunan.

Kabupaten Sumba Tengah merupakan wilayah administratif Provinsi Nusa Tenggara Timur yang terletak di wilayah Indonesia bagian Timur. Keadaan wilayahnya sangat bervariasi dan memiliki sektor unggulan yang menjadi perioritas utama untuk dikembangkan dengan memiliki daya dukung yang kuat antara lain sumber daya alam, sumber daya manusia.

Sektor yang menjadi unggulan pembangunan ekonomi wilayah Kabupaten Sumba Tengah adalah sektor pertanian, terlihat dari keadaan PDRB Kabupaten Sumba Tengah setiap tahunnya, dimana sektor pertanian merupakan penyumbang terbesar. Keadaan inilah sehingga pemerintah setempat merencanakan pengembangan sektor unggulan untuk menjadi perioritas yaitu sektor pertanian. Salah satu sub sektor prioritas yaitu perkebunan sebab terdapat komoditas prioritas utama untuk dikembangkan. Komoditas perkebunan memiliki nilai jual ekonomi yang tinggi baik tingkat lokal, nasional maupun internasional. Penyebabnya meningkatnya harga jual karenan kebutuhan bahan baku industri yang terus meningkat dan kebutuhan konsumen terhadap hasil industri perkebunan yang meningkat. Akibat inilah pada tahun 2014 pemerintah daerah Kabupaten Sumba Tengah melalui Dinas Pertanian, Perkebunan Dan Kehutanan menetapkan empat komoditi prioritas yang dikembangkan yaitu kopi, kakao, jambu mete dan kemiri. Komoditas ini dapat disebut komoditi strategis perkebunan Kabupaten Sumba Tengah. Perencanan pengembangan komoditi perkebunan mengalami kendala atau permasalahan disebabkan masih kurangnya imformasi komoditi unggulan perkebunan dan potensi wilayah seperti kondisi biofisik lahan, sosial, budaya dan kelembagaan. (Sitorus et al., 2014) mengatakan bahwa komoditas unggulan merupakan komoditas yang layak baik secara fisik (iklim dan tanah), sosial ekonomi dan kelembagaan untuk dikembangkan disuatu wilayah.Keadaan biofisik lahan sangat berpengaruh terhadap pertumbuhan dan perkembangan tanaman dan menentukan ketersedian unsur hara yang sangat diperlukan oleh tanaman, karena setiap tanaman memeliki kebutuhan yang berbeda, jika sesuai maka tingkat hasil produksinya tinggi.

Terdapat berbagai metode imformasi potensi lahan antata lain: metode evaluasi lahan komoditas pertanian berdasarkan pada syarat tumbuh tanamanan yang dinyatakan dalam (Djaenudin et al., 2003), penentuan komoditas unggulan dengan metode Location Quotien (LQ), dan arahan pengembangan dengan metode spasial. Terdapat berbagai penelitian dengan metode yang sama antara lain : 1) Penelitian (Tufaila et al., 2014), evaluasi kesesuaian lahan dengan metode pencocokan karakteristik lahan dan persayarat tumbuh tanaman di peroleh kelas kesesuaian lahan tanaman kopi dan jambu mete yaitu S2 (cukup sesuai) dengan luas 213,65 ha, S3 (sesuai marginal) seluas 37,01 ha dan N (tidak sesuai) seluas 3,01 ha; dan 2) Penelitian (Suryani et al., 2015) dalam penelitian penentuan komoditi unggulan dengan metode LQ dan arahan pengembangan dengan metode spasial dipeoleh tiga jenis komoditas unggulan perkebunan di Kabupaten Bungo yaitu karet, kelapa sawit dan kelapa dalam dan arahan pengembangan berdasarkan kesesuian lahan diperoleh komoditas karet di wilayah kecamatan palepat dan jujuhan dengan masing luas berturut 25.290 ha dan 22.414 ha.

Permasalahan inilah sehingga diperlukan sebuah kajian untuk menentukan kelayakan komoditas perkebunan prioritas yaitu kopi, kakao, jambu mete dan kemiri dengan ditinjau dari keunggulan komoditi komoditas terpilih, kesesuian lahan komoditi terpilih dan arahan wilayah potensi pengembangan lokasi komoditas terpilih.

\section{METODE PENELITIAN}

Penelitian ini dilakukan diwilayah administratif Kabupaten Sumba Tengah pada bulan desember 2016 sampai Januari 2017 dengan metode penelitian yang digunakan antara lain: Studi literatur terhadap pengembangan komoditas terpilih yaitu kopi robusta, kakao, jambu mete dan kemiri dari berbagai sumber yaitu buku, jurnal dan berbagai sumber lainnya.Menentukan komoditi unggulan dengan metode Location Quotien (LQ). Data yang digunakan yaitu data luas lahan panen dan hasil produksi dari tahun 2011 sampai 2015 yang diperoleh dari dari Dinas Pertanian, Perkebunan dan Kehutanan. Metode ini digunakan untuk menentukan apakah komoditi perkebunan prioritas Kabupaten Sumba Tengah merupakan komoditi basis atau tidak. Persamaan Location Quotien (LQ) :

$$
\begin{aligned}
& L Q=\frac{X_{i j} / X_{i .}}{X_{. j} / X_{. .}} \text {dengan: } \\
& \mathrm{Xij}=\text { Nilai luas panen atau produksi komoditas } \\
& \text { ke-J pada } \\
& \text { kecamatan ke-i } \\
& \mathrm{Xi}=\text { Jumlah seluruh luas panen atau produksi } \\
& \text { komoditas pada } \\
& \text { kecamatan ke-i } \\
& \mathrm{X}_{-}(. \mathrm{j})=\text { Jumlah nilai luas panen atau produksi J di } \\
& \text { seluruh } \\
& \text { kecamatan } \\
& \mathrm{X}_{-}(. \mathrm{j})=\text { Jumlah nilai luas panen atau produksi J di } \\
& \text { seluruh } \\
& \text { kecamatan }
\end{aligned}
$$


Interprestasi nilai LQ: 1) LQ > 1 Maka diindikasikan bahwa komoditas $\mathrm{j}$ tersebut unggul dan dapat dikembangkan di kecamatan ke i, atau melebihi kebutuhan seluruh wilayah dan dapat di eksport ke wilayah lain; 2) LQ $=1$, diindikasikan bahwa komoditas $\mathrm{j}$ tersebut hanya dapat memenuhi kebutuhan kecamatan $\mathrm{i}$ atau hanya memenhui kebutuhan seluruh wilayah; dan 3) $\mathrm{LQ}<1$, diindikasikan bahwa komoditas tersebut belum dapat memenuhi kebutuhan kecamatan i, sehingga diperlukan imfor dari wilayah lain.

Evaluasi kesesuaian lahan dengan tujuan untuk memperoleh kebutuhan sumber daya biofisik lahan (iklim dan tanah) tanaman perkebunan unggulan dengan penentuan kelas kesesuaian lahan dengan metode pencocokan karakteristik lahan dan persyaratan tumbuh komoditas perkebunan sejalan dengan pernyataan (Djaenudin et al., 2003). Data fisik lahan diperoleh dengan cara mengumpulkan data-data sekunder dan primer. Data sekunder diperoleh dari BAPPEDA Kabupaten Sumba Tengah (peta administrasi, peta kemiringan lereng, peta ketinggian tempat, peta penggunaan lahan dan peta jenis tanah) dan data iklim diperoleh dari Dinas Pertanian, Perkebunan dan Kehutanan Kabupaten Sumba Tengah . Pengambilan data primer berdasarkan hasil overlay peta dengan menentukan sampel berdasarkan karakter lahan berdasarkan teknik penentuan sampel secara purposive sampling diperoleh 15 titik sampel. Variabel biofisik lahan di uji yaitu keadaan iklim dan tanah. Variabel iklim yaitu suhu $\left({ }^{0} \mathrm{C}\right)$ dan curah hujan tahunan $(\mathrm{mm})$, variabel tanah yaitu tekstur tekstur, pH, N-total, $\mathrm{P}\left(\mathrm{P}_{2} \mathrm{O}_{5}\right)$ total, $\mathrm{K}\left(\mathrm{K}_{2} \mathrm{O}\right)$ total dan Bahan Organik. Karakter tanah di uji di Laboratorium Tanah Fakultas Pertanian dan Bisnis Universitas Kristen Satya Wacana. Teknik penentuan kelas kesesuian lahan dengan model builder, dengan presentase iklim 50\% dan unsur tanah 50\%.

Arahan pengembangan komoditas perkebunan unggulan dengan teknik kombinasi wilayah unggulan dan kesesuaian lahan tanaman, peta penggunaan lahan (exsisting) dan peta rencana tata ruang wilayah Kabupaten Sumba Tengah. Penggunaan peta ini dengan tujuan menghindari penggunaan lahan selain hutan yang terletak pada kawasan hutan konservasi atau Taman Nasional Manupeu Tanadaru (TNMT). Sehingga wilayah tersebut tidak dapat diperkenankan untuk dibudidayakan komoditi apapun selain hutan. Alat bantu analisis spasial yang digunakan yaitu Arview GIS ver. 3.2 dan QGIS ver 2.8.9.

\section{HASIL DAN PEMBAHASAN}

\section{Karakteristik lahan Kabupaten Sumba Tengah}

Secara geografis wilayah administrasi Kabupaten Sumba Tengah terletak diantara $9^{0} 20^{\prime}-9^{0} 50^{\prime}$ Lintang Selatan (LS) dan $119^{\circ} 20^{\prime}-119^{0} 50^{\prime}$ Bujur Timur (BT). Kabupaten Sumba Tengah memeliki luas wilayah administrasi 186.918 ha. Secara administrasi, Kabupaten Sumba Tengah memiliki 5 Kecamatan yaitu Katiku Tana Selatan, Katiku Tana, Mamboro, Umbu Ratu Nggay Barat dan Umbu Ratu Nggay.
Ditinjau dari ketinggian tempat, wilayah Sumba Tengah terletak pada rentang ketinggian 0-800 $\mathrm{m}$ dpl.

Keadaan iklim setempat, terletak pada wilayah semi arid Indonesia atau wilayah dengan curah hujan rendah dengan rentang curah hujan per tahun adalah 1800-2450 $\mathrm{mm} /$ tahun (Jawang et al., 2017). Rata-rata bulan basah hanya empat bulan dan delapan bulan kering selama satu tahun. Dapat dikatakan bahwa pertanian wilayah setempat merupakan pertanian lahan kering. Secara fisiografi bahwa wilayah setempat, sebagian wilayah memeliki tingkat kemiringan lereng yang rendah yaitu dengan presentase $0 \%$ sampai $25 \%$.

Sumba Tengah memiliki jenis tanah yaitu andisol, inceptisol, mollisol, ultisol dan vertisol. Ditinjau dari tingkat kesuburannya bahwa jenis tanah andisol dan inceptisol memeliki tingkat kesuburan rendah, mollisol dan ultisol memeliki tingkat kesuburannya sedang, sedangkan vertisol memliki tingkat kesuburanya sangat tinggi. Dipastikan bahwa wilayah Kabupaten Sumba Tengah memiliki tinggkat kesuburan tanahnya dari tingkat kesuburan rendah, sedang dan sangat tinggi (Jawang et al., 2017).

Berdasarkan hasil uji laboratorium ditinjau dari sifat harkat tanah diperoleh bahwa tekstur tanah wilayah setempat sangat beragam dimulai dari liat sampai berpasir, tingkat kemasama dari masam sampai netral dengan nilai $\mathrm{pH}$ pada rentang 5,16 - 7,14, kandungan bahan organik dari sangat rendah sampai sangat tinggi dengan nilai pada rentang $0,25 \%-12,03 \%$, kandungan nitrogen total dari sangat rendah sampai sangat tinggi dengan rentang nilai $0,02 \%$ $1,09 \%$, keadaan fosfat total sangat rendah dengan rentang nilai $1,03 \%-1,26 \%$ dan kalium total dalam tanah rentang nilai $0,01 \%-0,07 \%$. Kedaaan variable inilah menentukan wilayah yang memeliki potensi pengembangan komoditas perkebunan unggulan berdasarkan tingkat kelas kesesuaian lahan komoditas strategisrkebunan. Karakter tanah setiap lokasi sampel seperti pada tabel 1. Komoditi perkebunan Kabupaten Sumba Tengah masih berstatus sebagai perkebunan rakyat. Pengembangan komoditi perkebunan diwilayah Sumba Tengah, masih terbatas disebabkan pemahan tentang nilai jual komoditi perkebunan, dan panen hasil perkebunan mebutuhkan waktu yang cukup lama. Budidaya tanaman perkebunan masih hanya pada usaha tani sampingan, yang mengakibatkan luasan tanaman perkebunan relatif kecil untuk setiap petani.

Potensi lahan pertanian cukup tinggi di Kabupaten Sumba Tengah terlihat dari data penggunaan lahan basah dan lahan kering. Luasan lahan kering cukup tinggi dibandingakan dengan lahan basah dengan luas lahan kering 141.836 ha atau 75,88\% dari total luas lahan Sumba Tengah. Data luas penggunaan lahan seperti pada tabel 2.

\section{Keadaan Komoditas Perkebunan Unggulan}

Berdasarkan penelitian (Zakiah et al., 2015) menngatakan bahwa komoditas perkebunan unggulan wilayah adalah komoditas yang memeliki nilai basis dari luas lahan panen dan nilai hasil produksi 
Tabel 1. Karakter tanah lokasi sampel di Kabupaten Sumba Tengah

\begin{tabular}{l|c|c|c|c|c|c}
\hline \multicolumn{1}{c|}{ Lokasi Sampel } & $\begin{array}{c}\text { Kelas } \\
\text { Tekstur }\end{array}$ & $\mathrm{pH}$ & $\begin{array}{c}\text { Bahan } \\
\text { Organik (\%) }\end{array}$ & N Total (\%) & P Total (\%) & K Total (\%) \\
\hline Makatul, KTS & $\mathrm{C}$ & 5,52 & 12,03 & 1,09 & 1,03 & 0,02 \\
\hline Wairasa, URNB & $\mathrm{C}$ & 5,16 & 2,84 & 0,17 & 1,10, & 0,05 \\
\hline Padira Tana, URN & $\mathrm{C}$ & 5,39 & 1,14 & 0,27 & 1,25 & 0,03 \\
\hline Padira Tana, URN & $\mathrm{C}$ & 5,37 & 3,24 & 0,04 & 1,26 & 0,05 \\
\hline Soru, URN & $\mathrm{C}$ & 6,36 & 1,59 & 0,19 & 1,10 & 0,04 \\
\hline Tana Mbanas, URN & $\mathrm{C}$ & 6,50 & 2,06 & 0,29 & 1,17 & 0,05 \\
\hline Tana Mbanas, URN & $\mathrm{L}$ & 6,65 & 1,62 & 0,05 & 1,14 & 0,03 \\
\hline Tana Mbanas, URN & $\mathrm{S}$ & 6,82 & 0,35 & 0.05 & 1,01 & 0,02 \\
\hline Lenang, URN & $\mathrm{SL}$ & 6,84 & 2,02 & 0,22 & 1,10 & 0,04 \\
\hline Lenang, URN & $\mathrm{LS}$ & 7,06 & 0,25 & 0,07 & 1,04 & 0,01 \\
\hline Manu Wolu, M & $\mathrm{SiCL}$ & 7,14 & 1,52 & 0,02 & 1,10 & 0,07 \\
\hline Waimanu, KTS & $\mathrm{C}$ & 7,06 & 1,76 & 0,03 & 1,24 & 0,03 \\
\hline Manurara, KTS & $\mathrm{C}$ & 7,08 & 10,02 & 0,14 & 1,17 & 0,02 \\
\hline Tana Modu, KTS & $\mathrm{C}$ & 6,85 & 1,59 & 0,05 & 1,12 & 0,02 \\
\hline Konda Maloba, KTS & $\mathrm{C}$ & 6,95 & 10,23 & 0,28 & 1,19 & 0,02 \\
\hline Keterangan; KTS Kativ Tan
\end{tabular}

Keterangan; KTS : Katiku Tana Selatan, URNB: Umbu Ratu Nggay Barat, URN : Umbu Ratu Nggay, M: Mamboro.C:liat, L: Lempung, S:Pasir, SL: Lempung Berpasir, LS: Pasir Berlempung, dan SiCL: Lempung Liat berdebu

Tabel 2. Luas penggunaan lahan untuk pertanian di Kabupaten Sumba Tengah

\begin{tabular}{l|r|r|r|r}
\hline \multirow{2}{*}{ Kecamatan } & \multicolumn{4}{c}{ Penggunaan Lahan } \\
\cline { 2 - 5 } & \multicolumn{1}{c|}{ Luas (ha) } & Sawah (ha) & Lahan Kering (ha) & Lainnya (ha) \\
\hline Katiku Tana & 7.883 & 986 & 6.292 & 290 \\
\hline Katiku Tana Selatan & 36.834 & 2.585 & 19.229 & 15.020 \\
\hline Mamboro & 35.859 & 882 & 32.802 & 2.175 \\
\hline Umbu Ratu Nggay & 79.137 & 1.393 & 60.130 & 17.614 \\
\hline Umbu Ratu Nggay Barat & 27.205 & 1.961 & 23.383 & 1.861 \\
\hline \multicolumn{1}{c}{ Total } & 186.918 & 8.122 & 141.836 & 36.960 \\
\hline
\end{tabular}


Tabel 3. Nilai LQ komoditas perkebunan setiap kecamatan di Kabupaten Sumba Tengah

\begin{tabular}{|c|c|c|c|c|c|c|c|c|c|c|c|c|c|c|c|}
\hline \multirow[b]{3}{*}{ Komoditas } & \multicolumn{15}{|c|}{ Kecamatan } \\
\hline & \multicolumn{3}{|c|}{ Katiku Tana } & \multicolumn{3}{|c|}{ Katiku Tana Selatan } & \multicolumn{3}{|c|}{ Mamboro } & \multicolumn{3}{|c|}{ Umbu Ratu Nggay } & \multicolumn{3}{|c|}{ Umbu Ratu Nggay Barat } \\
\hline & $\begin{array}{c}\text { Luas } \\
\text { Panen } \\
\text { (ha) }\end{array}$ & $\begin{array}{l}\text { Produksi } \\
\quad(\text { ton })\end{array}$ & $\begin{array}{c}\text { Rerata } \\
\text { LQ }\end{array}$ & $\begin{array}{c}\text { Luas } \\
\text { Panen } \\
\text { (ha) }\end{array}$ & $\begin{array}{l}\text { Produksi } \\
\quad \text { (ton) }\end{array}$ & $\begin{array}{c}\text { Rerata } \\
\text { LQ }\end{array}$ & $\begin{array}{c}\text { Luas } \\
\text { Panen } \\
\text { (ha) }\end{array}$ & $\begin{array}{l}\text { Produksi } \\
\quad \text { (ton) }\end{array}$ & $\begin{array}{c}\text { Rerata } \\
\text { LQ }\end{array}$ & $\begin{array}{c}\text { Luas } \\
\text { Panen } \\
\text { (ha) }\end{array}$ & $\begin{array}{l}\text { Produksi } \\
\quad \text { (ton) }\end{array}$ & $\begin{array}{c}\text { Rerata } \\
\text { LQ }\end{array}$ & $\begin{array}{c}\text { Luas } \\
\text { Panen } \\
\text { (ha) }\end{array}$ & $\begin{array}{l}\text { Produksi } \\
\quad \text { (ton) }\end{array}$ & $\begin{array}{c}\text { Rerata } \\
\text { LQ }\end{array}$ \\
\hline $\begin{array}{l}\text { Jambu } \\
\text { Mete }\end{array}$ & 0.057 & 0.031 & 0.044 & 0.486 & 0.307 & 0.396 & 1.704 & 1.249 & 1.477 & 1.150 & 1.622 & 1.386 & 0.404 & 0.240 & 0.322 \\
\hline Kelapa & 1.064 & 1.716 & 1.390 & 1.035 & 1.432 & 1.234 & 0.671 & 0.710 & 0.691 & 1.130 & 0.727 & 0.928 & 1.305 & 1.431 & 1.368 \\
\hline Kopi & 1.604 & 1.842 & 1.723 & 1.458 & 1.948 & 1.703 & 0.984 & 0.871 & 0.928 & 0.658 & 0.581 & 0.620 & 0.931 & 1.109 & 1.020 \\
\hline Kakao & 1.582 & 1.975 & 1.779 & 2.556 & 3.137 & 2.846 & 1.082 & 1.143 & 1.112 & 0.218 & 0.137 & 0.177 & 0.704 & 0.808 & 0.756 \\
\hline Pinang & 1.461 & 1.493 & 1.477 & 1.036 & 1.233 & 1.134 & 0.477 & 0.617 & 0.547 & 1.204 & 0.882 & 1.043 & 1.337 & 1.509 & 1.423 \\
\hline Sirih & 2.598 & 2.144 & 2.371 & 1.563 & 1.397 & 1.480 & 0.386 & 0.317 & 0.351 & 0.845 & 1.117 & 0.981 & 1.127 & 1.176 & 1.151 \\
\hline $\begin{array}{l}\text { Jarak } \\
\text { Pagar }\end{array}$ & 1.132 & 0.692 & 0.912 & 2.372 & 2.089 & 2.230 & 1.385 & 1.609 & 1.497 & 0.247 & 0.378 & 0.313 & 0.494 & 0.728 & 0.611 \\
\hline Kemiri & 0.668 & 0.722 & 0.695 & 0.555 & 0.690 & 0.622 & 1.306 & 1.327 & 1.317 & 0.936 & 0.808 & 0.872 & 1.019 & 1.101 & 1.060 \\
\hline Asam & 0.550 & 0.421 & 0.485 & 0.827 & 0.510 & 0.669 & 0.734 & 0.530 & 0.632 & 1.552 & 0.859 & 1.205 & 0.991 & 2.595 & 1.793 \\
\hline Kapuk & 2.766 & 3.094 & 2.930 & 3.459 & 4.669 & 4.064 & 0.542 & 0.624 & 0.583 & 0.329 & 0.185 & 0.257 & 0.327 & 0.266 & 0.296 \\
\hline
\end{tabular}


Tabel 4. Kelas Kesesuaian Lahan Komoditas Strategis Perkebunan Kabupaten Sumba Tengah

\begin{tabular}{|c|c|c|c|c|c|c|c|c|}
\hline \multirow{2}{*}{ Kecamatan } & \multicolumn{2}{|c|}{ Kopi } & \multicolumn{2}{|c|}{ Kakao } & \multicolumn{2}{|c|}{ Jambu Mete } & \multicolumn{2}{|c|}{ Kemiri } \\
\hline & Kelas & Luas (ha) & Kelas & Luas (ha) & Kelas & Luas (ha) & Kelas & Luas (ha) \\
\hline \multirow[t]{3}{*}{ Katiku Tana } & $\mathrm{S} 1$ & 7847.441 & $\mathrm{~S} 1$ & 4111.956 & S1 & - & S1 & 7874.506 \\
\hline & $\mathrm{S} 2$ & 27.064 & S2 & 3762.014 & S2 & 4460.124 & S2 & - \\
\hline & S3 & - & S3 & - & S3 & 3413.846 & S3 & - \\
\hline \multirow{3}{*}{$\begin{array}{l}\text { Katiku Tana } \\
\text { Selatan }\end{array}$} & $\mathrm{S} 1$ & 28931.275 & $\mathrm{~S} 1$ & 31308.795 & $\mathrm{~S} 1$ & - & S1 & 36735.486 \\
\hline & S2 & 7803.192 & S2 & 5427.992 & S2 & 32948.591 & S2 & - \\
\hline & S3 & - & S3 & - & S3 & 3789.245 & S3 & - \\
\hline \multirow[t]{3}{*}{ Mamboro } & $\mathrm{S} 1$ & 6167.096 & $\mathrm{~S} 1$ & 32768.426 & S1 & 5594.936 & S1 & 34272.776 \\
\hline & $\mathrm{S} 2$ & 29657.172 & $\mathrm{~S} 2$ & 3052.152 & $\mathrm{~S} 2$ & 29285.578 & S2 & 1550.565 \\
\hline & $\mathrm{S} 3$ & - & $\mathrm{S} 3$ & - & S3 & 941.393 & S3 & - \\
\hline \multirow[t]{3}{*}{ Umbu Ratu Nggay } & S1 & 54027.475 & $\mathrm{~S} 1$ & 16055.692 & S1 & 0 & S1 & 59477.884 \\
\hline & S2 & 25024.601 & S2 & 62999.754 & S2 & 33455.555 & S2 & 19577.746 \\
\hline & S3 & - & S3 & - & S3 & 45597.714 & S3 & - \\
\hline \multirow{3}{*}{$\begin{array}{l}\text { Umbu Ratu Nggay } \\
\text { Barat }\end{array}$} & $\mathrm{S} 1$ & 26690.714 & $\mathrm{~S} 1$ & 19082.658 & S1 & 120.881 & S1 & 27206.341 \\
\hline & S2 & 515.627 & S2 & 8123.502 & S2 & 26511.416 & S2 & - \\
\hline & S3 & - & S3 & - & S3 & 573.862 & S3 & - \\
\hline
\end{tabular}


Tabel 5. Arahan wilayah potensi pengembangan masing- masing komoditas strategis

\begin{tabular}{|l|c|c|c|c|}
\hline \multirow{2}{*}{\multicolumn{1}{|c|}{ Kecamatan }} & \multicolumn{3}{c|}{ Arahan Pengembangan } \\
\cline { 2 - 5 } & Kopi & Kakao & Jambu Mete & Kemiri \\
\hline Katiku Tana & Potensi & Potensi & Kurang Potensi & Cukup potensi \\
\hline Katiku Tana Selatan & Potensi & Potensi & Kurang Potensi & Potensi \\
\hline Mamboro & Cukup potensi & Potensi & Cukup potensi & Potensi \\
\hline Umbu Ratu Nggay & Cukup potensi & Kurang Potensi & Cukup potensi & Cukup potensi \\
\hline Umbu Ratu Nggay Barat & Cukup potensi & Cukup potensi & Cukup potensi & Potensi \\
\hline
\end{tabular}

Luas panen diasumsikan bahwa menentukan kemampuan lahan mendukung pertumbuhan dan perkembangan tanaman dan produksi menentukan daya dukung lingkungan, sosial dan ekonomi sangat mendukung. Berdasarkan hasil analsis LQ pada tabel 3, diperoleh komoditas unggulan wilayah pada setiap kecamatan yaitu1) Kecamatan Katiku Tana memiliki enam komoditi unggulan yaitu Kapuk, Sirih, Kakao, Kopi, Pinang, dan Kelapa; 2) Kecamatan Katiku Tana Selatan memiliki tujuh komoditi unggulan yaitu Kapuk, Kakao, Jarak Pagar, Sirih, Kopi, Pinang, dan Kelapa; 3) Kecamatan Mamboro memiliki empat komoditi unggulan yaitu: Jarak Pagar, Kemiri, Jambu Mete, dan Kakao; 4) Kecamatan Umbu Ratu Nggay memiliki satu komoditi unggulan yaitu: Jambu Mete; dan 5) Kecamatan Umbu Ratu Nggay Barat memiliki empat komoditi unggulan yaitu : Pinang, Kelapa, Sirih dan Kemiri.

Dari empat komoditi strategis atau komoditas prioritas pengembangan di Kabupaten Sumba Tengah diurutkan berdasarkan jumlah wilayah kecamatan basis. Komoditi kakao memiliki wilayah basis ditiga Kecamatan yaitu Katiku Tana, Katiku Tana Selatan dan Mamboro; Komoditi kopi memiliki wilayah basis didua kecamatan yaitu Katiku Tana dan Katiku Tana Selatan; Komoditi Jambu Mete memiliki wilayah basis di dua kecamatan Katiku Tana Selatan dan Mamboro; dan Komoditi kemiri memiliki wilayah basis di dua kecamatan yaitu Mamboro dan Umbu Ratu Nggay Barat.

Setelah diperoleh hasil wilayah basis atau unggulan masing-masing komoditas maka dilanjutkan dengan ditinjau dari kriterian kesesuian lahan setiap komoditas dengan tujuan untuk memaksimalkan pengembangan keempat komoditas strategis dan menentukan komoditas yang memeliki potensi untuk dikembang di wilayah Kabupaten Sumba Tengah.

\section{Kelas Kesesuaian Lahan Komoditas Perkebunan Unggulan}

Berdasarkan hasil presentase setiap unsur iklim dan tanah diperoleh kelas kesesuian lahan setiap komoditas prioritas atau strategis Kabupaten Sumba Tengah. Tanaman kopi dengan luas kesesuian masing-masing kelas yaitu kelas S1 (sangat sesuai) dengan luas 123.664 ha atau 66,2\% dari total luas lahan, S2 (cukup sesuai) dengan luas 63.027,7 atau $33,7 \%$ dari total luas lahan dan $\mathrm{N}$ (tidak sesuai) dengan luas: 226 atau $0,1 \%$ dari total luas. Tanaman kakao dengan luas kesesuian lahan masing-masing kelas yaitu S1 (sangat sesuai) dengan luas 103.327,5 atau 55,3\%, S2 (cukup sesuai) dengan luas $83.365,4$ atau $44,6 \%$ dan $\mathrm{N}$ (tidak sesuai) dengan luas: 225 ha atau $0,1 \%$; Tanaman jambu mete dengan luas kesesuian masing-masing kelas yaitu S1 (sangat sesuai) dengan luas: 5.716 ha atau $3 \%$, S2 (cukup sesuai) dengan luas: $126.661,3$ atau $67,8 \%$, S3 (sesuai marginal) dengan luas: 54.313,1 atau 29,1 \% N (tidak sesuai) dengan luas: 228 atau 0,1\%. Tanaman kemiri dengan luas kesesuian masing-masing kelas S1 (sangat sesuai) dengan luas : 165.567 atau $88,6 \%$, S2 (cukup sesuai) dengan luas: $21.128,3$ atau 11,3\%, $\mathrm{N}$ (tidak sesuai) dengan luas 223 atau $0,1 \%$. Wilayah tingkat kelas kesesuian lahan setiap empat komoditas terpilih terlihat secara spasial pada gambar 1 .

Berdasarkan pencocokan keadaan biofisik lahan Kabupaten Sumba Tengah dan persyaratan tumbuh tanaman diperoleh faktor pembatas untuk setiap tanaman, penyusunan faktor pembatas disusun berdasarkan pengaruh biofisik tersebut terhadap tanaman perkebunan penyusunan berdasarkan kelas dari N,S3 dan S2. Tanaman kopi dengan faktor pembatasnya adalah tekstur, kemiringan lahan, suhu, kadar N, kadar P, kadar K, pH dan Bahan Organik. Faktor pembatas untuk tanaman kakao yaitu tekstur, kemiringan lahan, kadar $\mathrm{N}$, kadar $\mathrm{P}$, kadar $\mathrm{K}, \mathrm{pH}$, suhu dan bahan organik. Tanaman jambu mete faktor pembatasnya adalah suhu udara, tekstur, suhu, curah hujan, kadar N, kadar P, kadar K dan bahan organik. Tanaman kemiri dengan faktor pembatasnya yaitu tekstur, kemiringan lahan, kadar N, kadar $\mathrm{P}$, kadar K dan bahan organik.

Faktor pembatas Iklim tidak dapat dirubah, karena sifatnya permanen. (Tufaila et al., 2014) mengatakan bahwa iklim merupakan faktor pembatas yang sangat sulit untuk diperbaiki. Keadaan iklim dapat diatasi dengan memperhitungkan keadaan cuaca dan curah hujan, sedangkan suhu dapat di usahan dengan penentuan wilayah pengembangan berdasarkn suhu wilayah (Parcawijaya et al., 2015) . Sedangkan faktor pembatas tanah, dilakukan usaha pengelolaan konservasi meliputi pembuatan teras, penanaman berdasarkan arah kontur dan penanaman tanaman penutup tanah. Upaya pemupukan bila kekurangan unsur hara seperti bahan organi, N, P,K dan pH. Bila faktor pembatas dapat diatasi maka diharapkan produktifitas komoditi dapat meningkat. 


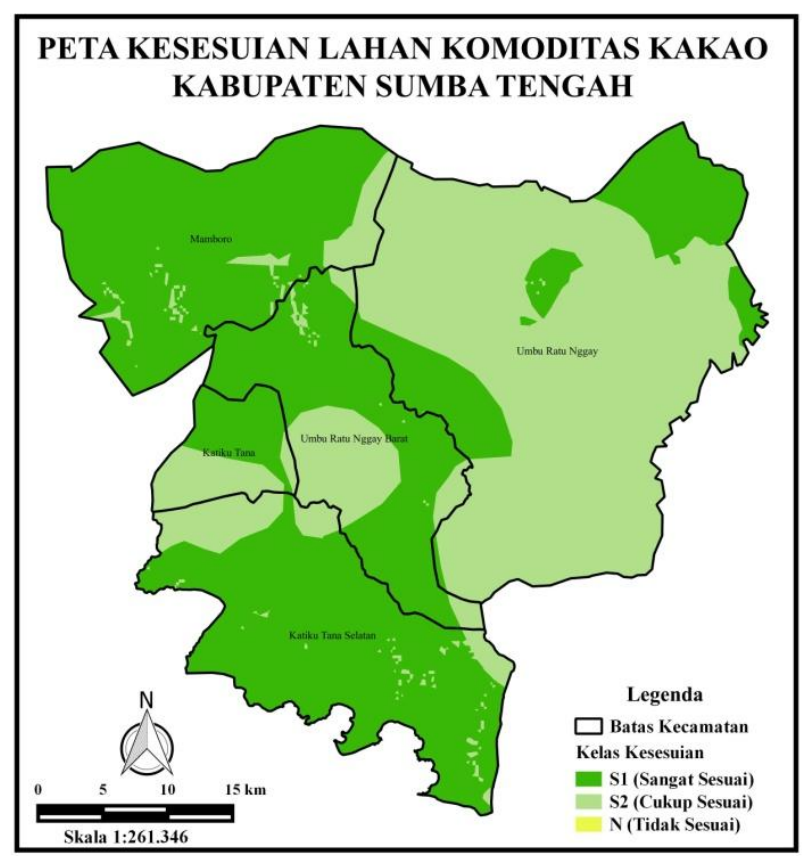

Peta Kesesuian Lahan Komoditas Kakao

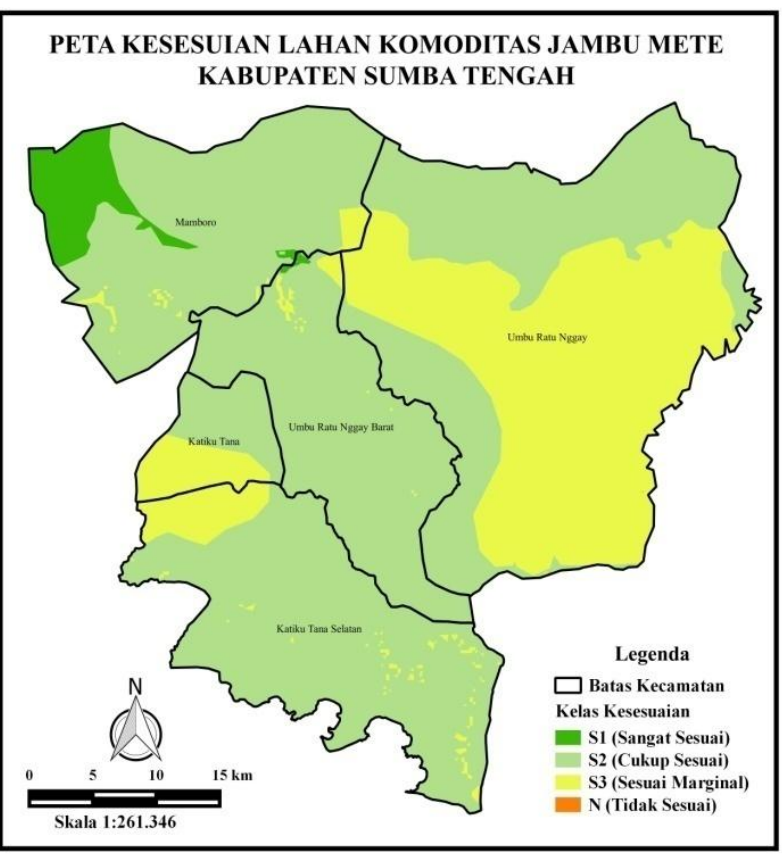

Peta Kesesuian Lahan Komoditas Jambu Mete

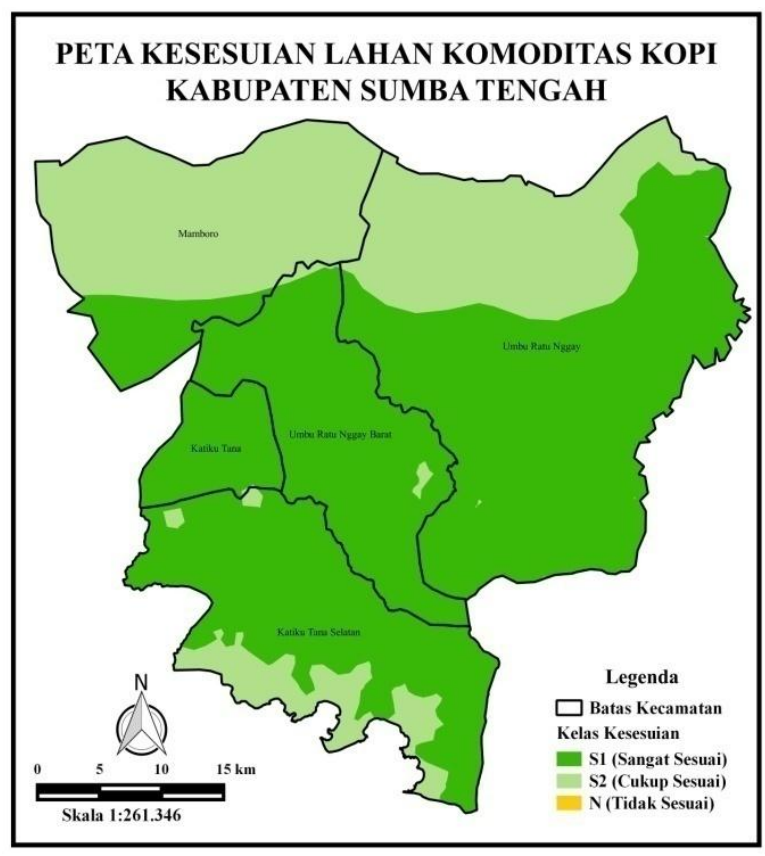

Peta Kesesuian Lahan Komoditas Kopi Arabika

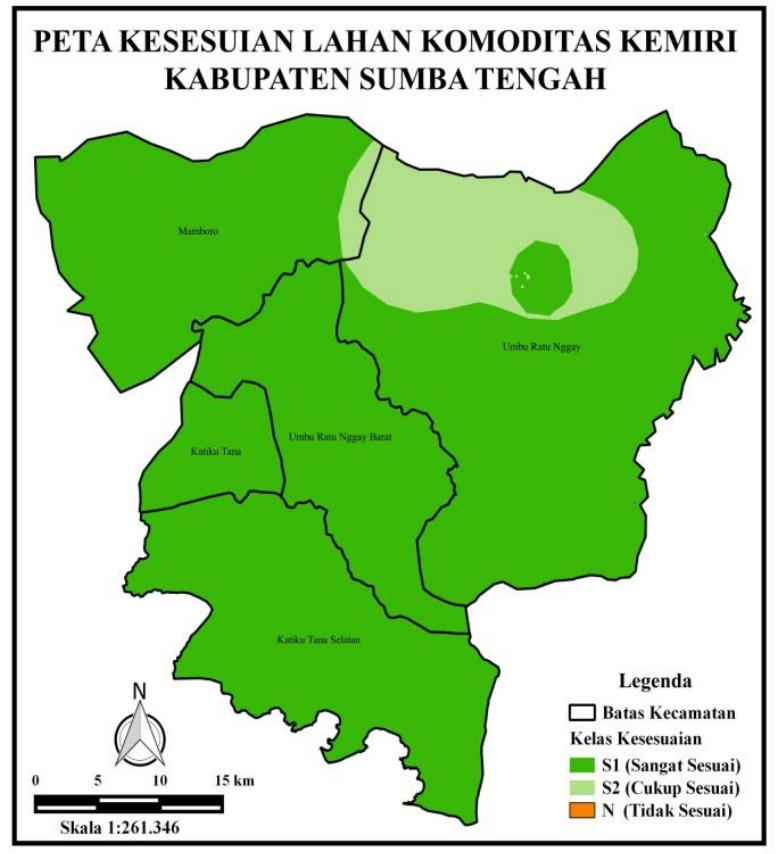

Peta Kesesuian Lahan Komoditas Kemiri

Gambar 1. Peta kesesuaian lahan komoditas strategis perkebunan Kabupaten Sumba Tengah

\section{Arahan Pengembangan Komoditas Unggulan}

Arahan pengembangan wilayah perlu disusun, sebab setiap wilayah memliki potensi masing-masing. Pengembangan wilayah berbasis prioritas perlu dipertimbangkan berdasarkan potensi wilayah pengembangan komoditas tersbut. Setiap tanaman memeliki syarat tumbuh masingmasing atau membutuhkan karakteristik biofisik lahan yang berbeda. Perencanaan pengembangan komoditas terpilih atau komoditas prioritas perlu diperhatikan ketersedian lahan budidaya,

sehingga arahan wilayah pengembangan komoditas dapat terlaksana dengan baik, Dalam penentuan ketersedian lahan yang ditinjau dari rencana tata ruang wilayah (RTRW) Kabupaten Sumba Tengah, tersedianya kawasan lindung dan kawasan budidaya. Salah satu kawasan lindung yang diperhatikan yaitu kawasan Taman Nasional Manupeu Tana Daru (TNMT). Berdasarkan peta RTRW bahwa kawasan 
taman nasional terletak di tiga wilayah kecamatan yaitu Katiku Tana Selatan, Umbu Ratu Nggay Barat dan Umbu Ratu Nggay. Dari ketiga kecamatan, kecamatan katiku tana selatan dengan luas terbesar. Dari data RTRW luas lahan kawasan lindung taman nasional yaitu 34.790 ha atau dari $17 \%$ dari luas wilayah kabupaten. Maka luas kawasan budidaya 152.128 ha, luas kawasan budidaya yang dapat dimanfaatkan dalam pengembangan komoditas prioritas.

Arahan pengembangan komoditas masing-masing komoditas berdasarkan hasil analisis gabungan ketersedian lahan, Location Quotient (LQ) dan kesesuaian lahan komoditas pada setiap kecamatan. Arahan wilayah pengembangan masing-masing komoditas strategi terlihat pada tabel 5 .

\section{KESIMPULAN}

Sebaran lokasi komoditas strategis, Kakao dengan wilayah unggulan di Kecamatan Katiku Tana, Katiku Tana Selatan, dan Mamboro, dengan luas tingkat kesesuian lahan luas kelas S1: $103.327,5$ ha atau 55,3\%, S2: 83.365,4 ha atau $44,6 \%$ dan $\mathrm{N}: 225$ ha atau $0,1 \%$. Arahan wilayah potensi pengembangan di Kecamatan Katiku Tana, Katiku Tana Selatan dan Mamboro. Komoditas kopi dengan wilayah unggulan di Kecamatan Katiku Tana dan Katiku Tana Selatan, dengan luas wilayah tingkat kesesuian lahan luas kelas S1 123.664 ha atau 66,2\%, S2: 63.027,7 ha atau $33,7 \%$ dan $\mathrm{N}: 226$ ha atau $0,1 \%$. Arahan wilayah potensi pengembangan komoditas kopi di Kecamatan Katiku Tana dan Katiku Tana Selatan. Komoditas jambu mete dengan wilayah unggulan di Kecamatan Mamboro dan Umbu Ratu Nggay, dengan tingkat kesesuaian lahan kelas S1: 5.716 ha atau $3 \%, \mathrm{~S} 2: 126.661,3$ ha atau 67,8\%, S3: 54.313,1 ha atau $29,1 \%$ dan N: 228 ha atau 0,1\%. Sehingga arahan wilayah pengembangan komoditas jambu mete hanya cukup potensi di Mamboro, Umbu Ratu Nggay dan Umbu Ratu Nggay Barat. Komoditas kemiri dengan unggulan wilayah di Kecamatan Mamboro dan Umbu Ratu Nggay Barat, dengan luas tingkat kelas kesesuian lahan kelas S1: 165.567 ha atau $88,6 \%$, S2: $21.128,3$ ha atau 11,3\% dan N: 223 ha atau $0,1 \%$. Sehingga diperoleh arah wilayah potensi pengembangan Kecamatan Katiku Tana Selatan, Mamboro dan Umbu Ratu Nggay Barat.

\section{DAFTAR PUSTAKA}

Andi, P. F. 2006. Arahan Perwilayahan Komoditas Unggulan di Kabupaten Kotawaringin Timur. Tesis. Program Pascasarjana. Universitas Diponegoro. Semarang

Banjarnahor, Dina; Simanjuntak, B. H. 2016. Evaluasi Kesesuaian Lahan Sumba Tengah Untuk Tanaman Pangan Serta Perencanaan Polatanamnya Yang Spesifik Lokasi. Bumi Lestari 16(2): 108-118.

Barus, B. J. A., Razali, \& Sitanggang. 2015. Evaluasi Kesesuian Lahan untuk Tanaman Kopi Arabika (Coffea Arabica L var Kartika) di Kecamatan Muara
Kabupaten Tapanuli Utara. Agroekoteknologi 3(4): 1459-1467.

Djaenudin, D., Marwan, H., Subagjo, H., dan Hidayat, H. 2003. Petunjuk Teknik Evaluasi Lahan Untuk Komoditas Pertanian. Balai Penelitian Tanah: Bogor.

Hati, I. Permata. \& Sardjito. 2013. Arahan Pengembangan Komoditas Unggulan di Kabupaten Muara Enim Sumatera Selatan. Teknik POMITS 2(1): 1-5.

Holyman, A., Munir, M., dan, \& Sulaeman, Y. 2017. Integrasi SIG dan SPKL Untuk Evaluasi Kesesuian Lahan Tanaman Kopi Robusta dan Arahan Pengembangan Pertanian di Kabupaten Lahat, Sumatera Selatan. Tanah Dan Sumber Daya Lahan 4(2: 589-597.

Jawang, U.P., Simanjuntak, B.H, dan Prihtanti, T. M. 2017. Evaluasi Zona Agroekologi Kabupaten Sumba Tengah Berbasis Sistem Imformasi Geografis. Prosiding Konser Karya Ilmiah "Menghadapi Tantangan dan Meraih Kemandirian Pertanian Indonesia". Salatiga 05 mei 2017.

Jayanti, Dewi sri, Geonadi, S., Dan, \& Hadi, P. 2013. Evaluasi Kesesuaian Lahan Dan Optimasi Penggunaan Lahan Untuk Pengembangan Tanaman Kakao ( Theobroma cacao L .) ( Studi Kasus di Kecamatan Batee dan Kecamatan Padang Tiji Kabupaten Pidie Propinsi Aceh ). Agritech 33(2): 208-218.

Kandari, A. M., Safuan, L. A. O. D. E., \& Amsil, L. M. 2013. Evaluasi Kesesuaian Lahan Untuk Pengembangan Tanaman Kopi Robusta ( Coffea canephora ) Berdasarkan Analisis Data Iklim Menggunakan Aplikasi Sistem Informasi Geografi Land Suitability Evaluation for Development of Coffee Robusta ( Coffea canephora ) Based. Jurnal Agroteknos 3(1): 8-13.

Keratorop, M. 2016. Arahan Pengembangan Komoditas Unggulan Pertanian Tanaman Pangan di Kabupaten Boven Digoel, Provinsi Papua. Tesis. Sekolah Pascasarjana. Institut Pertanian Bogor. Bogor

Liyanda, M., Karim, A., Yusya, \& Abubakar. 2013. Analisis Kriteria Kesesuian Lahan Terhadap Produksi Kakao pada Tiga Klaster Pengembangannya di Kabupaten Pidie. Manajemen Sumber Daya Lahan 2(3): 270-284

Makaborang, M., Goenadi, S., \& Hadi, P. 2009. Optimasi Penggunaan Lahan Berdasarkan Kelas Kesesuian Lahan Untuk Pengembangan Tanaman Perkebunan (Studi Kasus: Kabupaten Sumba Timur Provinsi Nusa Tenggara Timur). Agritech 29(4): 188-197.

Mawardi, I. 2007. Perencanaan Pembangunan Wilayah Berdasarkan Konsep Produktifitas Unggulan. Tek. 
Ling 8(2): 181-187.

Nurleli. 2008. Pengembangan Komoditas Unggulan Perkebunan di Kabupaten Tanggamus Propinsi Lampung. Tesis. Sekolah Pascasarjana. Institut Pertanian Bogor. Bogor

Parcawijaya, R., Darsiharjo, dan Jupri. 2015. Evaluasi Kesesuaian Lahan Untuk Tanaman Kopi (Coffea Arabica) di Desa Sirnajaya. Antologi Geografi 3(2): $1-11$.

Ritung, S., Wahyunto, Agus, F., \& Hidayat, H. 2007. Panduan Evaluasi Kesesuaian Lahan Dengan Contoh Peta Arahan Penggunaan Lahan Kabupaten Aceh Barat. Balai Penelitian tanah dan World Agroforestry Centre (ICRAF). Bogor

Silaban, S. H., Sitorus, B., \& Marbun, P. 2016. Evaluasi Kesesuaian Lahan untuk Tanaman Kopi Arabika (Coffea arabica), Kentang (Solanum tuberosum L.), Kubis (Brassica oleraceae L.) dan Jeruk (Citrus Sp.) di Kecamatan Harian Kabupaten Samosir. Agroekoteknologi, 4(3): 2055-2068.

Setianto, Pawit; Susilowati, I. 2014. Komoditas Perkebunan Unggulan yang Berbasis Pada Pengembangan
Wilayah Kecamatan di Kabupaten Banjarnegara Provinsi Jawa Tengah. Wilayah Dan Lingkungan 2(2): 143-156.

Sitorus, S.R.P., Mulya, S.P., Iswati, A., Panuju, D.R., dan Iman, L. O. S. 2014. Teknik Penentuan Komoditas Unggulan Pertanian Berdasarkan Potensi Wilayah Dalam Rangka Pengembangan Wilaya. Prosiding Seminar Nasional Aspi "Mengembangkan Kota dan Wilayah Yang Tangguh dan Berkelanjutan". Pekanbaru, 17-18 Oktober 2014: 396-406.

Suryani, L.; Sitorus, S.R.P.; Minibah, K. 2015. Analisis Komoditas Perkebunan Unggulan dan Arahan Pengembangannya di Kabupaten Bungo, Provinsi Jambi. Littri 21(4): 175-188.

Tufaila, M., Aliyaman, Ginting, S., dan Alam, S. 2014. Evaluasi Kesesuaian Lahan Untuk Tanaman Kopi, Kakao, dan Jambu Mete di Kecamatan Moramo Utara Kabupaten Konawe Selatan. Agroteknos 4(3): $167-173$.

Zakiah, Safrida, dan Santri, L. 2015. Pemetaan Komoditas Unggulan Sub Sektor Perkebunan Di Kabupaten Aceh Selatan. Agrisep 16(1): 35-52. 